\title{
18. In Conquest of the World and of Modernity: Movements from the Countryside to Paris in Novels by Stendhal, Balzac and Flaubert
}

Annika Mörte Alling

French, Lund University

The works of Stendhal, Balzac and Flaubert have travelled across continents, survived through the centuries and have been abundantly translated, re-issued and read worldwide. This could be seen as proof of their quality and canonical position. Still, if we put them on the reading lists of our university courses, it should not simply be with reference to their status as classics and adherence to a western, European canon; we need to be able to explain to our students why we put these authors there, how they are relevant to us now and important to the literature that came after, and not only in a European context. Consequently, researchers also should deal with these questions; we need to study what makes the nineteenth-century French novels interesting today, in a global perspective. ${ }^{\mathrm{I}}$

I A few studies have been published in the last six years that place these authors in a larger perspective. Jennifer Yee's The Colonial Comedy: Imperialism in the French Realist Novel (Oxford: Oxford University Press, 20I6) treats colonial elements in Balzac, Flaubert and Zola. See also Christie McDonald and Susan Suleiman, ed., The French Global. A New Approach to Literary History (New York: Columbia University Press, 20II).

How to cite this book chapter:

Mörte Alling, Annika. "In Conquest of the World and of Modernity: Movements from the Countryside to Paris in Novels by Stendhal, Balzac and Flaubert". In World Literatures: Exploring the Cosmopolitan-Vernacular Exchange, edited by Stefan Helgesson, Annika Mörte Alling, Yvonne Lindqvist, and Helena Wulff, I99-2 I0. Stockholm: Stockholm University Press, 20I8. DOI: https://doi.org/IO.I6993/bat.r. License: CC-BY. 
One means of doing so is to examine how these works have been received and valued in different parts of the world, in the past up to the present. In the case of canonical authors such as these, comparative transhistorical examinations are in fact possible. There are already reception studies of for instance Stendhal in China, Japan, Sweden and the United States, and to compare them would mean a new more global contribution to Stendhalian research (this is my objective in another study). ${ }^{2}$ Such a reception analysis, however, needs to be combined with close readings of the novels, an approach that is often neglected in world literature studies. Even if "distant reading" 3 is often necessary when we are interested in literature on a global scale, we need to analyse the texts closely to discover the local, vernacular elements in the novels, those that relate, for instance, to the characters, their emotions and experiences of the world. In fact, it may be necessary to examine these elements to understand why we can enjoy, relate to and feel involved in a literary text in different times and places.

In this chapter one important element or theme in the nineteenth-century French novel will be discussed, namely the movement from small, rural contexts to the modern, cosmopolitan city, ultimately Paris. It will be analysed briefly in three novels, representing different types of realism: Le Rouge et le Noir by Stendhal (1830), Illusions Perdues by Honoré de Balzac (I843) and Madame Bovary by Gustave Flaubert (I 857 ). This quick overview should only be seen as an introductory reflection; a

${ }^{2}$ For China, see Qian Kong, La traduction et la reception de Stendhal en Chine I922-20I3, Honoré de Champion (to be published). For Japan: Julie Brock, ed., Réception et créativité. Le cas de Stendhal dans la littérature japonaise moderne et contemporaine, Berne: Peter Lang, 20I I, 20I3, vol. I and 2. For Sweden: Annika Mörte Alling, La réception de Stendhal en Suède, in L'Image du Nord chez Stendhal et les Romantiques IV. Études comparées. Textes réunis par Kajsa Andersson, vol 4. Örebro: Örebro university, 2007, I3-42. For the USA: Maud S. Walther, La présence de Stendhal aux États-Unis I8I8-I920 (Aran: Éditions du Grand Chêne, I974).

3 Franco Moretti, “Conjectures on World Literature", New Left Review I (2000): 57-58. 
coming study will analyse the theme more profoundly and also include examples from other novels, mainly by Balzac and Zola.

Even if several aspects of the displacement from the countryside to the metropolis have been studied before, for instance the role of Paris in the nineteenth-century novel and that of the countryside in Balzac's and Stendhal's work, there is more to say about the subject, notably in relation to world literature studies. ${ }^{4}$ I will focus here on the main characters' initial situations in the countryside and on how they are affected emotionally by the force that drives them to transgress their confined locations, in direction of Paris, the "Capital of the Nineteenth-Century", 5 and the new modern world. As we shall see, the literature that the protagonists read plays an important role in this transgression. Let us keep in mind the question of the global perspective and see what can be concluded at the end; how can a close reading of a literary text reveal its relevance to many people, across time and space?

The immediate starting point of Stendhal's Le Rouge et le Noir is the small provincial town of Verrières in Franche-Comté, at first sight very attractive with its white beautiful houses, the river Doubs, and the snow-covered mountaintops of the Jura. The observer of this idyllic setting is a first-time visitor from Paris. In reality, Verrières is quite an "intolerable" place though, the narrator informs us, since it is dominated by "the most offensive despotism" ("le plus ennuyeux despotisme"), as is life in small towns in general. ${ }^{6}$

4 See for instance Christopher Prendergast's important Paris and the Nineteenth Century (Oxford: Wiley-Blackwell, I995). For the role of the countryside in Balzac's novels, see Nicole Mozet's La ville de province dans l'ouvre de Balzac (Paris: Sedes, 1982) and the more recent study by Andrew Watts, Preserving the Provinces - Small Town and Countryside in the Work of Honoré de Balzac (Oxford: Peter Lang, 2007). The countryside in Stendhal has been studied by for instance Cécile Meynard in Stendhal et la province (Paris: Honoré Champion, 2005).

5 Walter Benjamin, The Capital of the Nineteenth Century, The Arcades Project (Cambridge: Harvard University Press, I999).

${ }^{6}$ Stendhal, The Red and the Black, trans. Horace B. Samuel (New York: E.P. Dutton and Co., I9I 6), 29, http://www.gutenberg.org/ebooks/44747; Stendhal, Le Rouge et le Noir (Paris: Gallimard, I972), 22. 
It is in this intolerable milieu that we later meet the protagonist, young Julien Sorel, who is represented as an exceptional character, being in the wrong place, doing absolutely the wrong thing. He is reading a book, on a roof by the sawmill, where he ought to have been working, too deeply concentrated to hear his father's angry calls. Père Sorel hits him violently twice, making him bleed profusely. In fact, no other activity is more odious to this old man, himself illiterate: "So that's it, is it, lazy bones! always going to read your damned books are you [...]?”7 (“-Eh bien, paresseux! tu liras donc toujours tes maudits livres [...]?”

Julien is pale, weak and has delicate traits and tears in his eyes (mostly because of the loss of his "beloved" book that fell down from the roof). ${ }^{9} \mathrm{He}$ clearly stands out in this harsh countryside milieu - also inhabited by his two violent brothers - and his inferiority invites us to feel sorry for him. This representation of the hero, and perhaps also his symbolically superior position on the rooftop, tell us on whose side the author is.

The book Julien is reading is the Memorial de SainteHelene, which constitutes his “coran”, together with Rousseau's Confessions and the Bulletins de la Grande Armée. ${ }^{\text {Io }}$ From these books he gets his vision of the world and a desire to succeed, to make a fortune, which above all means leaving Verrières - since "everything that he saw there froze his imagination" ("[t]out ce qu'il y voyait glaçait son imagination") - and being "presented one day to the pretty women of Paris" ("présenté aux jolies femmes de Paris"). ${ }^{\text {II }}$

Julien's readings not only inspire him to trangress the limit of the countryside and other geographical and social limits, they also give him the strength and power to achieve these transgressions. By learning to recite the Bible by heart he gets a position as tutor to M. de Rênal's children, and then a place in Abbé Pirard's seminary in Besançon. After that he gets to work as secretary for the

7 Stendhal, The Red and the Black, 53.

8 Stendhal, Le Rouge et le Noir, 32.

9 Stendhal, The Red and the Black, 44.

to Stendhal, Le Rouge et le Noir, 35 .

ir Stendhal, The Red and the Black, 69; Stendhal, Le Rouge et le Noir, 39. 
Marquis de La Mole in Paris and even to be the lover of the beautiful Parisian lady Mathilde de La Mole, thus realising one of his most important desires.

The movement from the province to Paris is important in novels by Balzac too, as is well known. Paris is the centre for art, literature and politics and the most obvious destination for the individuals determined to succeed, like Rastignac and Lucien Chardon. Madame de Bargeton in Illusions Perdues exhorts Lucien to leave Angoulême and start a new life in Paris :

There, beloved, is the life for a man who has anything in him. [...] Paris, besides, is the capital of the intellectual world, the stage on which you will succeed; overleap the gulf that separates us quickly. You must not allow your ideas to grow rancid in the provinces; put yourself into communication at once with the great men who represent the nineteenth century. ${ }^{\mathrm{I2}}$

Là, cher, est la vie de gens supérieurs. [...] D’ailleurs Paris, capitale du monde intellectuel, est le théâtre de vos succès! franchissez promptement l'espace qui vous en sépare! Ne laissez pas vos idées se rancir en province, communiquez promptement avec les grands hommes qui représenteront le XIXe siècle. ${ }^{\mathrm{I3}}$

As in Stendhal, the displacement from the countryside is charged with symbolic and emotional significance. The protagonists are in search of a kind of general fulfilment, of a self-realisation, of an understanding of the new modern world that Paris symbolises and includes. Reading literature is an important means for trying to understand this new world, and it also offers comfort and meaning in itself, not least in the countryside, which is often an intellectually as well as emotionally confined place. Reading Schiller, Gœthe, Lord Byron, Walter Scott, Lamartine and André Chenier, among others, is a unique source of happiness for Lucien and his friend David Séchard in the otherwise austere and passionless

${ }^{12}$ Honoré de Balzac, Lost Illusions, trans. Ellen Marriage (2004), http:// www.gutenberg.org/ebooks/I 3 I 59, 323-324.

${ }^{13}$ Honoré de Balzac, Illusions perdues (Paris: Gallimard, Folio classique, I974), I 59. 
environment, dominated by David's father (as unwilling to understand the point of this activity as Père Sorel). Absorbed by these texts, they forget about the sorrows of the countryside, cry together and plan for a future of fame and success: "Incessantly they worked with the unwearied vitality of youth; comrades in poverty, comrades in the consuming love of art and science, till they forgot the hard life of the present, for their minds were wholly bent on laying the foundations of future fame" ("dévorés par l'amour de l'art [...], ils oubliaient la misère présente en s'occupant à jeter les fondements de leur renommée"). ${ }^{\mathrm{I}}$ For Lucien, this future means glory as a writer - in Paris, as Madame de Bargeton helps to convince him in the longer citation above. Madame de Bargeton herself is an even more passionate reader than Lucien, suffering greatly from the monotony of the countryside. She adores Lord Byron and JeanJacques Rousseau, and longs strongly for a life in Paris. Despite initial doubts, she is able to realise this desire and travels to the capital together with Lucien in the beginning of the novel's second part.

In Madame Bovary too, the countryside, Normandy in this case, is represented as a narrow-minded world that in no way satisfies the desires of the main character. An important difference from Stendhal's and Balzac's novels is that Emma is herself part of this ordinariness and part of the monotony she complains about. She is not an exception, but in much behaving like most women of the countryside suffering from ennui, for instance reading romantic novels about love. As Julien, Lucien and David, she finds a certain comfort in her reading - it is one of the few activities she can indulge in where she is - and obtains her vision of reality from books such as Paul et Virginie and Ivanhoe by Walter Scott.

Unfortunately, Emma is unable to adapt her desires to reality, suffering from a pathological version of "bovarysme", a term defined by the philosopher Jules de Gaultier in I902, as "the faculty of man to conceive of himself as other than he is, and to conceive of the world as other than it is" ("la faculté qu'a l'homme de se concevoir autre qu'il n'est et de concevoir le monde autre”). ${ }^{\text {I5 }}$

\footnotetext{
${ }^{14}$ Balzac, Lost Illusions, 6I; Illusions perdues, 53.

I5 Jules de Gaultier, Le Bovarysme - Essai sur le pouvoir d'imaginer (Paris: Société du Mercure de France, I902), Io (English translation mine).
} 
In fact, Emma wants more from her life than the village people surrounding her, and so much more than her husband Charles Bovary, who "taught nothing, knew nothing, wished nothing" ("n'enseignait rien, celui-là, ne savait rien, ne souhaitait rien"). ${ }^{16}$ In this respect, Emma too can be regarded as an exceptional character, despite Flaubert's intentions to make her ordinary and to write a novel about "nothing" ${ }^{17}$ It is not the substance of her dreams that is extraordinary - Flaubert underlines their ordinariness with great irony - but her strong belief in them and her power to trangress limits to try to realise them, limits that no one else in the Normandy countryside would think possible or even desirable to transgress. After her marriage to Charles she moves to Tostes, later to the bigger town Yonville, and then tries to get closer to the city of her dreams, by reading about Parisian life in magazines and novels by Honoré de Balzac and George Sand. She even buys a map of the capital and walks up and down the streets with her fingertip. Emma never reaches Paris, but often visits the bigger town Rouen and adopts certain habits of a metropolitan woman; she wears expensive dresses in Parisian style and takes lovers, Rodolphe and later Léon.

In view of Emma's strong desires and her determination to realise her dreams, one cannot help wondering if she would have been able to realise her Parisian dream in more modern times, had she read different books and been able to move more freely as a woman, like Thérèse Désqueyroux, the eponymous heroine of François Mauriac's novel from I927. After all, Thérèse succeeds in liberating herself from her suffocating situation and marriage in the province of Les Landes, goes to Paris in the end with her mind set to begin a new life there, even to take courses at the

${ }^{16}$ Gustave Flaubert, Madame Bovary, trans. Eleanor Marx-Aveling (2006) https://www.gutenberg.org/files/24I3/24I3-h/24I3-h.htm, Chapter 7; Gustave Flaubert, Madame Bovary (Paris: Gallimard, I972), 72.

${ }^{17}$ During the period when he was working with Madame Bovary, Flaubert wrote to Louise Colet that he wanted to create a book about "nothing", almost without subject, whose strength would be in its style, since he meant that the most beautiful works were those without content. (Letter to Louise Colet I 6 January I 852 , in Gustave Flaubert, Correspondance Paris: Gallimard, I998, I 56. ) 
university. In fact, without the adaptation problem, Bovarysme is a positive capacity, a constructive force, that makes us challenge conventions, strive forward and discover new things. This is what Jules de Gaultier concluded in the later part of his book Le Bovarysme from I902. ${ }^{18}$

It is of course difficult to draw conclusions from the very brief observations in this chapter. It is also important to point out that the negative conception of the countryside context as a source of frustration and confinement is only the view of the main characters; it is by no means represented in the novels uniformly. We noted the narrator's descriptions of beautiful Verrières in the beginning of Stendhal's novel. It is obvious too that not all countryside inhabitants behave as Père Sorel and his rival, certainly not the kind-hearted Mme de Rênal. In Balzac's novels, as Andrew Watts has shown, countryside behaviour and people are condemned, as well as celebrated. ${ }^{19}$ Even in Madame Bovary a positive view of the province is represented, that of Charles, who is quite content with what it has to offer. Regarding the conception of Paris in the novels mentioned here, this is of course quite complex too. Paris becomes many different things, even from the perspective of a single character in the process of discovering a new sense of the self and the world. The dynamics between local and cosmopolitan contexts could even be studied within the Parisian world of one single novel (here the novels of Zola would definitely also be interesting material). Finally, it should be noted that the

${ }^{18}$ In other words, Jules de Gaultier is cited incorrectly in most encyclopedias and dictionaries; what is seen as his definition of Bovarysme is taken from the initial discussion about Emma Bovary, which later in his volumnious book takes a different turn. He then modifies his definition and concludes that Bovarysme is a necessary human capacity and that Emma's case is a pathological version of this capacity. For a more detailed discussion, see Annika Mörte Alling, "Le bovarysme et le désir triangulaire. Deux théories sur l'être humain appliquées à la littérature" in Jules de Gaultier Le Bovarysme La psychologie dans l'œuvre de Flaubert. Suivi d'une série d'études réunies et coordonnées par Per Buvik, ed. Per Buvik (Paris: Éditions du Sandre, 2007), 23 I-50.

19 Watts, Preserving the Provinces, 24. 
functions of the literary texts read by the protagonists are various and diverse, as Joëlle Gleize has shown. ${ }^{20}$

However, this multiplication of perspectives does not prevent us from getting the impression that the texts analysed reveal something important about how human beings could experience the movement from local to global spheres described above. Even one single character represented as exceptional and unstable in its views can transmit important experiences to us. The indirect nature of the relation between fiction and reality, so often underlined by theorists, does not prevent this transmission of experience either. ${ }^{21}$ Whether we are receptive of it or not probably has to do with emotions - the emotions expressed in a particular novel, perhaps in connection to the characters' experiences, as well as the emotions that the novel incites in us for various reasons. The context and life experiences of the reader play an important role of course, but one may wonder if a certain literary work cannot provoke the same type of emotions in different times and places. That is one of the reasons why world literary studies need to accord importance to close readings of literary examples: fictional literature has a high potential to gives us access to other people's emotions and experiences. Literature also provides a unique version of reality in that it can appear all-encompassing, in that it can embrace so many elements of the world at the same time, at so many different levels. It can give an impression of the world as

${ }^{20}$ Joëlle Gleize, Le Double Miroir. Le livre dans les livres de Stendhal à Proust (Paris: Hachette Supérieur, I992). Gleize shows that books have many different functions in novels by Stendhal, Balzac and Flaubert, one of them being to represent reality, as objects among other objects that enhance the realistic effect. This function in particular is discussed in her study.

${ }^{21}$ See for instance Michael Riffaterre, "The Referential Fallacy", Columbia Review 57 (1978): 2I-35. As Vincent Jouve affirms, even if the knowledge about the world that literature can mediate always is of a multiple and uncertain kind, most theorists agree that literature has a cognitive function, and that it helps us to understand the reality that surrounds us. ("Quelle exemplarité pour la fiction?", in Littérature \& exemplarité, edited by Emmanuel Bouju et al., Rennes: Presses Universitaires de Rennes, 2007, 247). 
"knowable" and "graspable", in Caroline Levine's words. ${ }^{22}$ One single novel of Balzac - one single character even - can seem to contain the whole world.

In other words, by studying the movements of the above characters from the local to the global, from the familiar, limited context to larger and foreign spaces, we may learn something important about human beings in the process of transgressing limits and searching for meaning in an expanding world. Furthermore, the essential and sometimes creative role that literature plays for the characters in their movements makes us wonder if the authors are not trying to tell us something about the importance of reading literature to conceive of the world and of oneself as other and to be able to cross borders. There are many more examples of the creative type of reading in the French nineteenth-century novel. ${ }^{23}$

In the cases briefly analysed here, the reasons for the characters' need to move away from the rural contexts are not linked to war or poverty, but have to do with a desire of self-realisation and of approaching a modern world representing new possibilities for realising this desire. Other desires are encompassed by this existential project; to become successful, to belong somewhere, to find love and, simply, to be happy.

To know more precisely how the novels - each one in its specific manner - transmit these experiences, and if and how they can be interpreted as still "valid" for many people, empirical studies among readers from various sociocultural contexts would be

${ }^{22}$ In the article "How to make worlds" (Public Books, I I January 20I6, http://www.publicbooks.org), Caroline Levine discusses this worldmaking function of narratives in general and of artistic works of art, following the ideas of Martin Heidegger, Pheng Cheah and Mark Seltzer. As these theorists, Levine is critical of the large focus on the world as space in world literature research; we need to include other dimensions of the world in our studies, time for instance. We also need to include the literary texts themselves, since literature helps us grasp the world in time, as it "comes into being".

23 Even if the literature read by the characters of the French nineteenth-century novel often influences them in a delusive manner, their reading is above all creative, as Gleize points out (Le Double Miroir, II4-II5). However, she does not really analyse this creative function of the characters' reading. 
necessary, as pointed out in the beginning. In other words, close readings of the texts need to be put in relation to studies of their translation and reception.

\section{Bibliography}

Alling Mörte, Annika. “La réception de Stendhal en Suède”. In L'Image $d u$ Nord chez Stendhal et les Romantiques IV. Études comparées, edited by Kajsa Andersson, I3-42. Örebro: Örebro university, 2007.

—. "Le bovarysme et le désir triangulaire. Deux théories sur l'être humain appliquées à la littérature". In Jules de Gaultier Le Bovarysme La psychologie dans l'œuvre de Flaubert. Suivi d'une série d'études réunies et coordonnées par Per Buvik, edited by Per Buvik, 23 I-250. Paris: Éditions du Sandre, 2007.

Balzac, Honoré de. Illusions perdues. Paris: Gallimard, collection Folio classique, I974.

- Lost Illusions. Translated by Ellen Marriage. 2004. Accessed 20 August 2017. http://www.gutenberg.org/ebooks/I3 I 59.

Benjamin, Walter. The Capital of the Nineteenth Century. The Arcades Project. Cambridge: Harvard University Press, I999.

Brock, Julie, ed. Réception et créativité. Le cas de Stendhal dans la littérature japonaise moderne et contemporaine, vol. I and 2. Berne: Peter Lang, 20I I and 20I3.

Flaubert, Gustave. Correspondance. Paris: Gallimard, collection Folio classique, I998.

- Madame Bovary. Paris: Gallimard, collection Folio classique, I972.

-. Madame Bovary. Translated by Eleanor Marx-Aveling. 2006. https://www.gutenberg.org/files/24I3/24I3-h/24I3-h.htm.

Gaultier, Jules de. Le Bovarysme. Paris: Société du Mercure de France, I902 (later with the undertitle Essai sur le pouvoir d'imaginer).

Gleize, Joëlle. Le Double Miroir. Le livre dans les livres de Stendhal à Proust. Paris: Hachette Supérieur, I992. 
Jouve, Vincent. “Quelle exemplarité pour la fiction?” In Littérature \& exemplarité, edited by Bouju, Emmanuel, Gefen, Alexandre, Hautcœur, Macé, Marielle, 239-248. Rennes: Presses Universitaires de Rennes, 2007.

Kong, Qian. La traduction et la reception de Stendhal en Chine I922-2OI3. Paris: Honoré Champion. Forthcoming.

Levine, Caroline. "How to make worlds". Public Books, I I January (20I6). http://www.publicbooks.org/how-to-make-worlds/.

McDonald, Christie and Suleiman, Susan, ed. The French Global. A New Approach to Literary History. New York: Columbia University Press, 201 I.

Meynard, Cécile. Stendhal et la province. Paris: Honoré Champion, 2005 .

Moretti, Franco. "Conjectures on World Literature". New Left Review I (2000): 57-58.

Mozet, Nicole. La ville de province dans l'œuvre de Balzac. Paris: Sedes, I982.

Prendergast, Christopher. Paris and the Nineteenth Century. Oxford: Wiley-Blackwell, I995.

Riffaterre, Michael. "The Referential Fallacy”. Columbia Review 57 (I978): 2I-35.

Stendhal. Le Rouge et le Noir. Paris: Gallimard, collection Folio, I972.

The Red and the Black, A Chronicle of I 830. Translated by Horace B. Samuel. New York: E.P. Dutton and Co., I916. http:// www.gutenberg.org/ebooks/44747.

Walther, Maud S. La présence de Stendhal aux États-Unis I8I8I920. Aran: Éditions du Grand Chêne, I974.

Watts, Andrew. Preserving the Provinces Small Town and Countryside in the Work of Honoré de Balzac. Oxford: Peter Lang, 2007.

Yee, Jennifer. The Colonial Comedy: Imperialism in the French Realist Novel. Oxford: Oxford University Press, 2016. 